\title{
Pendampingan Usaha Dawet Siwalan (DILAN) Di Desa Hendrosari, Menganti, Gresik, Sebagai Upaya Menghidupkan Glokalisasi Di Masa Pandemi
}

\author{
${ }^{1}$ Lutfia Nurul Hidayati, ${ }^{2}$ Dwi Hardiningtiyas, ${ }^{3}$ Indriastuti \\ Universitas Wijaya Putra \\ lutfianurulhidayati@uwp.ac.id,dwihardaningtyas@uwp.ac.id, Indri_astuti63@yahoo,com
}

\begin{abstract}
ABSTRAK
Dawet berasal dari Jepara Jawa Tengah, namun sudah dikenal luas di berbagai wilayah di Indonesia karena rasanya yangunik. Minuman terenak versi CNN pada tahun 2018 mengalami inovasi pada pengolahannya. Es dawet yang adadi Desa Hendrosari, Kecamatan Menganti, Gresik, dipadukan dengan buah siwalan, sehingga menjadi Es Dawet Siwalan (DILAN). Penjualan DILAN dikelola di sentra penjualan siwalan dan wisata edukasi Hendrosari menjadi sorotan. Kualitas rasa yang diciptakan dan penyesuaian antara lokalitas dengan globalisasi, menjadi kajian yang menarik. Hal ini disebabkan semakin maraknya penjualan minuman cita rasa luar negeri. Dalammenghadapi globalisasi pelaku UMKM bukan merupakan hal yang mudah. Di tengah tuntutan globalisasi ekonomi, persaingan dengan perusahaan besar, dan juga inovasi yang serba cepat, pelaku UMKM membutuhkan bantuan yang berkelanjutan dari pihak yang peduli pada kebangkitan perekonomian. Salah satu hal yang menjadi permasalahan dalam meningkatkan produktivitas dan daya saing saat ini adalahmaraknya varian minuman "impor" di Indonesia. Sehingga, minuman lokal harus dikenalkan kembali dengan konsep yang baik, dalam kajian transformasi global: dengan Glokalisasi. Banyak hal yang harus diperhatikan, baik oleh pelaku usaha maupun pemerintah. Pengabdian masyarakat yang penulis lakukan memuat riset bagaimana pelaku usaha minuman DILAN bertahan di masa pandemi dan apa tantangan yang dihadapi di tengah arus globalisasi perekonomian.
\end{abstract}

Kata kunci : DILAN, Hendrosari, Glokalisasi

\section{PENDAHULUAN}

Di era global seperti saat ini, transformasi global adalah hal yang tidak dapat dihindari oleh individu maupun kelompok dalam kehidupan bermasyarakat. Transformasi atau perubahan pada salah satu bagian dalam masyarakat, cenderung pasti akan diikuti dengan perubahan lain, karena apabila masyarakat tidak mengikuti perubahan tersebut masyarakat akan tertinggal bila dibandingkan dengan masyarakat yang mengikuti perubahan. Saat ini pula, para remaja lebih tertarik dengan berbagai varian olahan keju baik dalam makanan maupun minuman. Sehingga pengabdian ini dilakukan untuk melihat bagaimana mempertahankan eksistensi produk lokal dan bagaimana produk tersebut dapat bertahan di era global. Karena untuk memenuhi kebutuhan pasar, para produsen minuman mulai berinovasi untuk menciptakan minuman dengan berbagai varian, salah satunya dengan memasukkan produk global yaitu keju.

Globalisasi merupakan sebagai sebuah proses meningkatnya keterkaitan antar masyarakat di seluruh dunia, sehingga fenomena apapun yang terjadi disuatu bagian dunia semakin memberi dampak terhadap masyarakat di belahan dunia yang lain. (Baylis dan Smith, dalam Hartanto 2018). Sedangkan menurut Held et al. (1999) (dalam Hartanto, 2018), globalisasi adalah sebuah proses yang mengimplementasikan transformasi dari organisasi spasial hubungan sosial dan transisi. Kemudian, menurut Hartanto, dari dua 
pandangan di atas, jelas bahwa globalisasi merupakan proses meningkatnya hubungan diantara individu baik itu negara maupun nonnegara dalam konteks relasi yang bersifat beragam baik itu politik, ekonomi, dan sosial budaya.

Dari proses globalisasi itu, muncul kemudian apa yang dinamakan dengan glokalisasi, yang menurut Roland Robertson (2001) (dalam Chaubet, 2013) : proses penginterpretasioan hal global dengan nilai lokal, dimana nilai tersebut diakui secara global. Pada akhirnya, globalisasi berjalan beriringan dengan lokalitas. Adanya interaksi antara budaya lokal dan budaya global tidak lagi bisa dipisahkan.

Berdasarkan hasil observasi atau pengamatan yang dilakukan oleh kami, semakin banyaknya minuman yang diadaptasi dari minuman kekinian di negara lain, terus menggerus eksistensi minuman tradisional. Semakin ketat persaingan dan juga semakin modern pengemasan minuman-minuman tersebut, secara langsung menunjukkan bahwa minuman khas Indonesia tidak dapat bersaing. Karena biasanya, minuman khas Indonesia tidak diperjualbelikan secara profesional baik dalam pemasaran maupun pengemasannya. Jika demikian, bukan tidak mungkin dikemudian hari eksistensi minuman lokal akan berakhir. Padahal, kandungan minuman lokal lebih menyehatkan daripada minuman yang mengandung aneka perisa dan bahan-bahan sintetis.

Sehingga menjadi penting bagi kami untuk mendorong sebuah produk lokal agar lebih banyak dijangkau oleh masyarakat di era saat ini. Dari segi harga dan pengaruhnya pada kesehatan, produk lokal lebih memiliki kualitas yang baik dibanding minuman dengan berbagai pengawet dan perasa buatan. Meskipun, kami menghadapi kenyataan bahwa generasi muda saat ini adalah yang sudah ter-McDonalisasi dengan produk luar. Penyebab hal ini terjadi karena saat ini dunia sudah tidak dibatasi oleh apapun akibat adanya globalisasi. Istilah McDonalisasi adalah istilah yang digunakan oleh Ritzer untuk menggambarkan fenomena adanya industri-industri besar yang menjalar atau berekpansi secara global dan kemudian mempengaruhi hal-hal yang berkenaan dengan budaya masyarakat (Ritzer, 2010).

Produksi minuman khas Indonesia memiliki tantangan yang cukup berat karena berkaitan dengan globalisasi; persaingan dalam meningkatkan ekonomi. Lebih jauh, hal ini menyangkut kemampuan pemilik usaha yang sudah mengetahui bagaimana pengemasan yang baik dan bagaimana menarik pembeli seperti yang dilakukan pengusaha kopi 'kekinian' dan minuman lainnya.

Minuman khas negara kita, Indonesia, tidak memiliki bargaining position atau posisi tawar yang menarik diantara aneka minuman 'hits' saat ini. Kita bisa lihat bagaimana ekspansi minuman khas Hongkong, Tiongkok, aneka kopi dan teh khas Arab, minuman aneka rasa yang dikemas sangat modern oleh unit usaha yang besar lebih dikenal oleh masyarakat dan lebih digandrungi kawula muda. Sehingga produk dari 'glokalisasi' minuman nusantara atau minuman Indonesia sangat diperlukan. Pengemasan, pengiklanan, dan kontrol kualitas secara baik -meskipun masih sekelas UMKM-mengikuti permintaan khas globalisasi, namun produk yang ditawarkan adalah inovasi lokal. Dengan demikian, kami yakin, dengan memberikan bantuan pada pengusaha dawet merupakan salah satu terobosan penting dalam glokalisasi.

Pemikiran untuk memulai pengabdian masyarakat dengan mitra kami (pengusaha dawet siwalan) berangkat dari pemahaman bahwa; meski menawarkan cerita cerah tentang peradaban dan makin kaburnya batas-batas negara, persebaran idea kesetaraan, kemakmuran ekonomi, keleluasaan akses, dan lainnya, tetap saja globalisasi mengandung sisi gelap. Sejatinya, terma globalisasi ini netral, hanya saja ketika di dalamnya terdapat neoliberalisme, maka globalisasi yang terjadi justru membuat hidup masyarakat -khususnya masyarakat kelas menengan ke bawahsemakin berat. Ada ketidaksetaraan dan kekalahan pengusaha kecil yang seharusnya 'dikuatkan' oleh regulasi negara dan upaya- 
upaya pemerintah (Effendi, 2020). Usaha-usaha kecil dan menengah seperti usaha dawet siwalan layak mendapat perhatian khusus, karena prosesnya yang masih konvensional, adanya kemauan pemilik usaha untuk mengolah dan menjual minuman yang masih tradisional sebagai pilihan lain aneka minuman modern seperti bobba dan teh-teh berkeju, lokasi unit usaha yang sedang dikembangkan untuk perekonomian dan edukasi masyarakat yang lebih baik, dan kualitas rasa minuman ini yang memiliki daya saing baik, kualitas rasa yang baik.

Kami memilih pengusaha dawet siwalan di daerah Hendrosari sebagai mitra juga karena kami melihat potensi di tengah situasi perekonomian yang belum stabil. Jika Edu Wisata ditutup, penjualan juga tidak mendapatkan hasil yang cukup untuk menutupi modal. Edu Wisata yang terkenal dengan sebutan Lontar Sewu ini merupakan tonggak utama dan jantung perekonomian masyarakat. Disebut sebagai Lontar Sewu karena memang ada banyak sekali Pohon Lontar di kawasan ini (surya.co.id). Kondisi Desa Hendrosari yang segmen pembelinya sebagian besar adalah wisatawan lokal juga menjadi perhatian kami. Ibu Sumiati sebagai pemilik usaha tidak mengerti konsep-konsep penjualan dengan sistem ekspansi juga seperti bergerak di tempat. Imbasnya, pemasukan dari usaha ini tidak seberapa. Padahal, seperti yang sudah kami sampaikan diatas, usaha minuman produk glokalisasi ini potensinya sangat besar dan dapat menjadi salah satu solusi perekonomian masyarakat.

Selain hal-hal khusus yang kami sampaikan diatas, pentingnya pengabdian masyarakat yang akan direalisasikan untuk pendampingan UMKM adalah agar UMKM kembali berkontribusi pada masa pandemi ini, sebagaimana yang Menteri Koordinator Bidang Perekonomian Airlangga Hartanto sampaikan bahwa aktor yang paling terdampak selama pandemi ini adalah mereka yang bergerak menjalankan UMKM. Padahal, UMKM adalah salah satu penopang perekonomian bangsa
Indonesia. Oleh karenanya, UMKM harus dibantu agar dapat bertahan dan dapat bersaing di ranah lokal (cnbcindonesia.com).

\section{METODE}

Langkah pertama, setelah mengetahui apa yang diperlukan oleh UMKM ini, adalah pemberian alat pendukung usaha yang diharapkan mampu meningkatkan efektivitas kerja pelaku UMKM. Alat pemotong siwalan belum ada yang secara diformulasikan khusus, namun kita dapat menemukan alat pemotong serupa yang nantinya bisa digunakan untuk mempercepat proses pengupasan dan pembentukan buah siwalan. Alat tersebut adalah Cubic Cutter yang diproduksi oleh Signora. Alat bantu tersebut akan sangat berguna jika diberikan pada pelaku usaha. Karena dapat mendukung keselamatan kerja karyawan mereka.

Usaha mikro yang bergerak dalam bidang usaha minuman ini dikelola masih sangat sederhana, sehingga alat pendukung atau alat bantu yang bisa diberikan juga jumlahnya tidak banyak. Anggaran untuk unit-unit bantuan ini sebesar Rp. 2.500.000. Terkait belum maksimalnya pemanfaatan media promosi, tim pengabdian masyarakat melakukan pelatihan untuk pelaku usaha dan karyawan. Hal ini menjadi penting dan akan melibatkan pihak eksternal yang memiliki keahlian dalam bidang promosi produk makanan atau minuman di media sosial. Kami bekerjasama dengan tiga pihak : pengusaha yang sudah berpengalaman (memiliki expertise mumpuni dalam penjualan daring), ahli desain visual dan pengelolaan marketplace, serta influencer Gresik Kuliner. Pembuatan video promosi yang melibatkan influencer juga akan dilakukan pada tahap ini. Luaran pada tahap ini adalah kemampuan untuk mempromosikan produk secara berkala, kemampuan membuat desain sederhana untuk media promosi, pemanfaatan endorsment, dan adanya video dokumenter tentang produk yang juga akan diiklankan di 'platform' lain.

Adapun pelatihan pembukuan 
sederhana yang menyusun dengan rapi serta sistematis keuangan yang telah, sedang, dan akan dipergunakan dalam usaha ini, dapat memanfaatkan kemampuan tim pengabdian masyarakat yang memiliki keahlian dalam bidang tersebut. Pembukuan atau perencanaan dan pencatatan keuangan sangat penting dalam kegiatan wirausaha mikro karena menurut beberapa jurnal, masalah keuangan ini adalah salah satu masalah utama usaha menengah kebawah. Kecenderungan memakai uang usaha untuk keperluan rumah tangga, tanpa adanya 'pemisahan' pengeluaran akan dengan mudah membuat bidang usaha redup bahkan gulung tikar. Kami dari tim pengabdian masyarakat membantu agar usaha Ibu Sumiati sebagai pengusaha minuman dawet siwalan membuat perencanaan keuangan yang baik dan terukur sehingga usaha tersebut dapat berkembang dan membantu perekonomian masyarakat sekitar.

Pelaksanaan kegiatan dilakukan secara daring dan luring dengan jumlah peserta terbatas dan tetap memenuhi protokol COVID19. Langkah pertama yang dilakukan adalah penyamaan persepsi dan persiapan kegiatan. Hal ini dan beberapa koordinasi setelahnya akan dilaksanakan secara daring. Setelah dilakukan penyamaan persepsi dan persiapan kegiatan, selanjutnya adalah pembelian alat dan penyerahan sekaligus pada hari itu juga akan dimulai pelatihan. Pelatihan tidak bisa dilaksanakan satu kali, melainkan harus beberapa kali pertemuan.

Pertemuan pertama adalah penyerahan alat bantu produksi oleh tim pengabdian masyarakat terhadap ketua atau pemilik badan usaha. Pada hari tersebut juga dimulai pembedahan masalah keuangan oleh tim yang memiliki keahlian dalam bidang tersebut. Setelah pertemuan pertama dilaksanakan, pertemuan selanjutnya dalah pelatihan desain visual sederhana, pengelolaan media sosial, dan tips-trik menarik pembeli dengan promosi produk UMKM.

Tahap selanjutnya adalah pembuatan media-media promosi, termasuk video promosi yang akan dimasukkan dalam jaringan Gresik Kuliner. Setelah tahap tiga terlaksana dan luaran yang dicanangkan menjadi jelas, tahap selanjutnya adalah pengontrolan yang kembali dilakukan secara daring oleh tim pengabdian masyarakat yang sifatnya kondisional. Sehingga permasalahan dalam bidang produksi, bisa terbantu oleh pengadaan unit pembantu produksi; permasalahan bidang manajemen bisa terbantu pemecahan masalahnya dengan pelatihan oleh yang memiliki ekspertis, dan permasalahan pemasaran dapat diatasi dengan pelatihan dan pembuatan sarana promosi oleh jaringan Gresik Kuliner, serta adanya pendampingan berkelanjutan hingga masa akhir proyek berakhir, yang diharapkan mampu meningkatkan penjualan dan branding di tengah masyarakat.

Tim pemegang proyek terjun langsung ke lokasi usaha dan mengundang para narasumber sesuai hari atau tanggal yang disepakati bersama. Partisipasi mitra dalam hal ini adalah sebagai peserta pelatihan dan diminta untuk membantu tim dalam melaksanakan kegiatan pelatihan.

Pada akhir sesi pengabdian, kami selaku tim melakukan 'bedah pembukuan usaha', melihat animo masyarakat sekitar usaha dan di luar usaha, dan melakukan evaluasi pada trafik media promosi. Tim akan kembali mengadakan pertemuan daring atau luring (sesuai dengan kondisi mendatang) dan meminta laporan langsung dan tertulis dari pemilik dan karyawan badan usaha tersebut. Adapun setelah kegiatan selesai dilaksanakan (kontrak berakhir), pemilik badan usaha diajak untuk membuat tayangan testimoni tentang kegiatan yang telah dilakukan dan permasalahan glokalitas produk ini akan kami ulas dengan menggandeng media daerah.

\section{PEMBAHASAN/HASIL}

Seperti yang telah disebutkan diatas, minuman ini merupakan minuman khas yang terbuat dari Gula Jawa, santan, dan siwalan. Rasanya yang unik dan menyegarkan dibungkus dengan plastik berbentuk gelas yang sudah disablon dengan logo dan tulisan "DILAN". Penjualan tidak stabil selama masa pandemi dan ditutupnya wisata di desa tersebut membuat 
kami berinisatif untuk membantu membangkitkan kembali geliat produk lokal. Kami mempromosikan produk tersebut dengan pendekatan Glokalisasi, penggabungan antara konsep global dan lokal. Kami bermaksud mengangkat posisi tawar minuman tradisional sehingga bisa bersaing di era global, dimana segala sesuatu bersifat borderless, menyebabkan banyak produk luar lebih disukai oleh masyarakat Indonesia.

Konsep Glokalisasi sendiri bukan konsep yang membutuhkan penjabaran yang rumit, dalam studi sosial humaniora, konsep ini sering digunakan untuk memecahkan permasalahan domestik suatu negara yang mengalami kelesuan dalam mempertahankan keotentikannya. Masyarakat yang memiliki usaha harus dibantu untuk menghadapi persaingan pasar dengan perombakan sistem penjualan dan re-branding: upaya yang dilakukan oleh pengusaha untuk mengubah total atau memperbaharui sebuah merk dagang yang telah ada agar menjadi lebih baik namun tetap berada atau berpegang pada tujuan awalnya (binus.ac.id).

Glokalisasi adalah gabungan dari globalisasi dengan budaya lokal setempat. Pertama kali yang mengenalkan konsep ini adalah Roland Robertson. (2001) (dalam Chaubet, 2013). Kata Glokalisasi diambil dari istilah jepang yaitu dochakuka yang pada dasarnya memiliki arti teknik bertani yang dimodifikasi dan dipadukan dengan keadaaan setempat. Hal ini tentu sangat menarik karena, dengan kata lain, glokalisasi bisa merupakan strategi pemasaran dengan menjual produk yang sesuai dengan apa yang diminati dan diinginkan di lingkungan sekitar. Adapun unsur-unsur yang krusial dalam proses glokalisasi adalah; dunia berkembang menjadi lebih terbuka dan plural, tidak ada batasanbatasan antar negara, sehingga topik mengenai pengabdian masyarakat ini menjadi pilihan kami karena diangkatnya minuman tradisional atau lokal tapi dengan pengemasan dan metode global. Kemudian antara aktor-aktor yang terlibat menjadi lebih inovatif dan terus mengikuti permintaan pasar.
Implementasi Glokalisasi bisa mudah dilakukan selama tidak ada kontradiksi antara produk dan upaya yang dilakukan. Jika produk minuman tradisional bisa diolah menjadi minuman yang memiliki nilai tawar lebih tinggi, maka hal tersebut tidak luput dari peran media sosial, media penjualan, pengemasan, cita rasa, dan bagaimana strategi penjualan yang baik dan benar. Glokalisasi dalam pendampingan usaha DILAN ini dilakukan dengan tahap yang jelas dan terukur untuk memantik tingkat produksi dan keberhasilan penjualan.

Setelah dilakukan serangkaian pendampingan usaha selama kurang lebih tiga bulan, usaha penjualan dawet siwalan semakin meningkat. Bahkan, pada saat stok siwalan habis, pengusaha minuman ini harus memutar otak bagaimana mendapatkan buah siwalan yang masih segar untuk dijadikan campuran dawet. Pada minggu pertama sejak penyerahan dan serangkaian pelatihan peningkatan hasil penjualan, usaha Ibu Sumiati berhasil mendapat respons baik dari peserta Kuliah Kerja Nyata yang kemudian bermaksud menjadi distributor DILAN (Dawet Siwalan) untuk area Surabaya dan sekitarnya. Meskipun Edu Wisata di Menganti ditutup, penjualan akhirnya tetap stabil dan memiliki banyak distributor di kotakota terdekat. DILAN juga kembali mengaktifkan media sosial, meskipun hanya sekedar untuk mengenalkan produk. Karena minuman ini sudah mulai dikenal di pasar luring. Penjualan DILAN setiap harinya mencapai 200 kemasan minuman dengan harga @Rp. 8.000 (Sumiati, 2021).

Berikut adalah hasil dari pendampingan usaha dawet siwalan yang dikelola oleh Ibu Sumiati di Desa Hendrosari, Kecamatan Menganti, Gresik, setelah dibina dan mendapat beberapa pelatihan, baik luring maupun daring: tahap pertama dalam pendampingan ini adalah pembelian alat yang dapat membantu efektivitas atau kecepatan dalam masa produksi. Pemberian ini didasari pada kebutuhan usaha, agar produksi meningkat dan dapat meringankan beban manusia dalam proses produksinya. Alat pemotong ini sangat penting 
dan posisinya sentral dalam pembuatan dawet siwalan. Sebelum adanya pembinaan dan penyerahan alat bantu, produksi tidak dapat dilakukan setiap hari karena terbatasnya tenaga dan sulitnya membuat siwalan berbentuk dadu. Namun, setelah adanya alat ini, produksi terus bisa dilakukan setiap hari selama persediaan siwalan masih ada. Lebih cepatnya proses ini tentu berimplikasi pada keseluruhan proses produksi. Penghasilan Ibu Sumiati tetap stabil bahkan meningkat setelah adanya alat bantu untuk membuat pemotong kubik.

Kedua, pada saat telah diberikan pelatihan desain visual sederhana dan promosi, Dawet Siwalan yang dikelola Ibu Sumiati di Gresik ini kembali menampilkan postingan promosi penjualan di media sosial. Memang ada banyak sekali penjual dawet siwalan di Desa Hendrosari, namun yang menjadi ikon dan sangat dikenal oleh masyarakat karena pengemasan dan tentu kualitas rasanya yang bersaing adalah UMKM yang dimiliki Ibu Sumiati. Usaha ini yang sempat berhenti mempromosikan produknya di berbagai kanal media, karena merasa sudah cukup berjualan secara offline saja, namun saat ini sudah kembali aktif dengan postingan dengan desain menarik meskipun sederhana dan hanya dari aplikasi Canva: alat untuk mendesain dan mempublikasikan karya yang lebih kolaboratif dari pada aplikasi lain, karena dapat diedit secara kolektif (canva.com). Pemesanan per hari yang dapat mencapai 200 pcs sebelumnya tidak diprediksi oleh tim dan oleh Ibu Sumiati sendiri. Promosi kemudian tidak dapat dilakukan secara gencar karena permintaan jauh lebih besar dari pada penawaran, sehingga jalan penjualan hanya dilakukan oleh produsen langsung ke konsumen atau melalui reseller yang sudah terdaftar dan dijatah dengan maksimal order setiap harinya. Bagaimanapun, grafis yang dirancang dengan baik memungkinkan untuk meningkatkan penjualan dan reputasi merek dan mencapai bisnis yang baik, sehingga meningkatkan fondasi bisnis yang berharga. Desain yang dipikirkan dengan matang dirancang untuk menjadi manusia. Tanpa perencanaan yang tepat, perusahaan tidak akan dapat berkonsentrasi pada produknya dan menumbuhkan pelanggannya di web yang berdampak pada keuntungan bisnis dan industri.

Ketiga adalah pelatihan pembukuan usaha sederhana. Hal ini menjadi penting karena selama ini,pelaku usaha tidak memperhatikan uang yang keluar dan masuk dalam usaha yang dikelolanya. Sehingga kadang usaha terus merugi atau tidak mendapatkan hasil yang sesuai karena tidak adanya pembedaan antara uang pribadi dengan uang modal usaha. Usaha dawet siwalan (DILAN) kemudian mengimplementasikan pencatatan yang baik meskipun masih sangat sederhana. Sebagai UMKM yang masih dalam kategori rintisan, pembuatan buku keuangan menjadi penting agar bisa mendapatkan profit maksimal. Pembukuan ini -meskipun masih dilakukan secara konvensional—pada akhirnya diharapkan dapat menjadi pembuka bagi modernisasi usaha-usaha lokal atau usaha yang dilakukan oleh warga lokal Indonesia.

Hasil yang kami dapat salah satu indikator keberhasilannya adalah ketika modal dan laba dalam satu bulan tercatat dengan lebih rapi, sehingga penghasilan maksimal dapat diraih karena tidak adanya percampuran antara pengeluaran "pribadi" dengan uang modal usaha. Pencatatan usaha yang dilakukan oleh staf Ibu Sumiati kemudian dapat diimplementasikan dalam berbagai jenis usaha. Pencatatan usaha tidak banyak dilakukan oleh pengusaha atau pekerja domestik di Indonesia. Pelatihan dan pengabdian masyarakat ini perlu digencarkan karena bisa menjadi instrumen yang baik dan bisa menjadi referensi gerakan baik untuk komunitas dan lembaga lain.

Pada saat melakukan pelatihan dan pembimbingan usaha dawet siwalan, merujuk pada strategi pemasaran produk oleh Jurnal Entrepeneur, kami membuat formula pelatihan dengan beberapa acuan: memberikan panduan strategi cepat untuk menunjang keberhasilan pemasaran produk, alat atau sarana dan prasarana dalam promosi produk, apa saja strategi yang bisa diterapkan, apa jenis pemasaran paling tepat, metode pemasaran 
yang paling baik, bagaimana melakukan promosi untuk produk pasar global, dan bagaiaman strategi pemasaran dan promosi pengusaha.

Kami kemudian memberikan pengarahan menyoal tujuh strategi pemasaran: 1) mengetahui target pasar sebelum menerapkan strategi pemasaran: semakin spesifik pasar yang dimaksud, semakin besar peluang untuk mendapatkan keberhasilan usaha. Dalam konteks ini, pangsa pasar dawet siwalan yang paling spesifik adalah masyarakat yang berkunjung atau berada di area Edu Wisata Hendrosari, Menganti, Gresik dan juga masyarakat di Kota Gresik dan Kota Surabaya. 2) optimalisasi peran media sosial dalam menjalankan program strategi pemasaran. 3) menawarkan produk secra gratis atau memberi tester untuk calon pembeli, calon agen, bahkan reseller, dapat menjadi langkah baik untuk mengenalkan produk pada target yang lebih luas lagi. 4) Memilih tempat yang strategis, dalma hal ini, lokasi UMKM binaan sudah cukup strategi karena berada di kota dan memiliki peluang besar karena adanya tempat wisata (pada saat pandemi lokasi ini tidak beroperasi secara normal). 5) Insentif untuk yang memasarkan (seperti metode endorsment). Pada bagian ke lima ini, kami memberikan suntikan dana agar usaha dawet siwalan dapat dikenal masyarakat melalui kanal instagram kuliner terbesar di Gresik, Jawa Timur. 6) kami juga memberikan penjelasan bagaimana menjalin hubungan baik dengan konsumen dan 7) kami mendorong agar usaha ini juga dikembangkan dengan teknik konvensional yakni dari mulut ke mulut (jurnal.id).

Setelah semua rangkaian pengabdian masyarakat kami lakukan, hasilnya bisa dilihat dari perkembangan usaha yang semakin tertata dan tampil sebagai inovasi industri di Gresik. Kami merasa bahwa masyarakat perlu untuk melihat realitas sosial di dalam diri masyarakat itu sendiri. Dengan melihat realita sosial yang ada, maka secara otomatis, jika memiliki kepedulian yang sama pada isu-isu peningkatan ekonomi, terutama di area yang sudah pernah atau akan menjadi tempat bersarangnya virus
COVID19, harapan kami adalah munculnya secara terus-menerus ide-ide segar dari akademisi dan peneliti untuk pengembangan program diantara masyarakat kelas menengah ke bawah. Pada tataran akar rumput, usaha dawet siwalan ini pantas diapresiasi dan mendapat perhatian pemerintah.

Ada banyak sekali hasil diskusi dan wawancara mendalam yang belum dianalisis, namun secara garis besar, kita dapat melihat pola peningkatan ekonomi dalam masyarakat di tengah wabah seperti ini. Semakin banyak dan baik inovasinya, semakin dikenal luas dan dapat menjadi alternatif dalam pemasaran secara online. Bersaing dengan minuman impor memang bukan hal mudah, karena selain selera, modal yang dikeluarkan oleh perusahaan tersebut sangat besar dan terencana. Sebaliknya, Usaha Menengah Kecil dan Mikro masih dijalankan dengan metode lama dan banyak yang tidak masuk dalam kontrol pemerintah. Namun, usaha peningkatan posisi tawar UMKM bukan hal itu sulit untuk diimplementasikan. Kita bisa memulai berpikir apa saja hal-hal yang bisa dikembangkan dari rumah dan lingkungan terkecil dengan daya jual yang tinggi. Penjualan dawet siwalan yang semakin sukses bisa menjadi percontohan untuk minuman-minuman khas nusantara lainnya.

\section{KESIMPULAN}

Globalisasi mendorong adanya 'persaingan' yang ketat dan inovasi yang tidak boleh berhenti jika menginginkan kemajuan, terutama dalam bidang ekonomi. Namun, globalisasi tidak selamanya harus ditempuh dengan 'caracara' yang selama ini kita kenal; elitis, penuh modal,d an tidak terjangkau oleh masyarakat atau pengusaha kelas menengah kebawah. Oleh karena itu, adanya konsepsi tentang Global dan Lokal sangat penting, terutama di negara-negara Asia. Penggabungan dua konsep besar ini bisa diturunkan menjadi metode menyukseskan usaha kecil dan menengah di Indonesia. Kami mencoba untuk melihat Glokalisasi sebagai alternatif di berbagai jenis usaha di tanah air, karena selain bisa dijangkau, hal ini bisa 
diimplementasikan karena sesuai konteks perekonomian warga Indonesia. Pengabdian kami di Desa Hendrosari, Menganti, Gresik, berangkat dari pemahaman bahwa minuman lokal bisa menjadi alternatif dan bisa menjadi pesaing bagi minuman impor dengan segala tantangannya di era global. Keberhasilan meningkatkan produktivitas dan pemberian mekanisme serta metode penjualan yang lebih rapi dan tertata, pada akhirnya (kami harap) bisa menjadi rujukan untuk usaha-usaha lain maupun kajian-kajian lain dalam Ilmu Sosial.

\section{REFRENSI}

\section{Buku}

Chaubet, Francois. (2013). Globalisasi Budaya. Yogyakarta: Jalasutra.

Effendi, Yusli, dkk. 2020. Glokalisasi : Gerakan Sosial, Kewargaan, dan Komunitas Sosial. Penerbit : Inetelegensia Media Malang

Ritzer, George \& Ataly, Zeynap. 2010. Reading in Globalization Key Concepts and Major Debates.

\section{Internet}

https://binus.ac.id/malang/2017/09/mengapa-

perlu-re-branding/

https://www.canva.com/id_id/about/

https://www.cnbcindonesia.com/tag/bantuan-

$\underline{\text { umkm }}$

https://productnation.co/id/10399/foodprocessor-bagus-terbaik-terbaru-indonesia/

https://www.jurnal.id/id/blog/strategipemasaran-produk-yang-harus-anda-coba/

https://surabaya.tribunnews.com/2021/04/21/lo ntar-sewu-edu-wisata-instagramable-di-desahendrosari-gresik-lokasi-favorit-untuk- $\underline{\text { ngabuburit }}$

\section{Sumber Lain}

Wawancara dengan Ibu Sumiati (Pemilik Usaha) 